\title{
SISTEM BASIS DATA PRODUKSI IKAN BERBASIS SITUS WEB (WEBSITE) DI KABUPATEN SUKABUMI - JAWA BARAT
}

\section{FISH PRODUCTION DATABASE SYSTEM BASED ON WEBSITE IN SUKABUMI REGENCY - WEST JAVA}

\author{
Imam Teguh Santausa ${ }^{1 *}$, Mustaruddin ${ }^{2}, \&$ Domu Simbolon ${ }^{2}$ \\ ${ }^{1}$ Program Studi Teknologi Perikanan Laut, Sekolah Pascasarjana, \\ IPB University, Bogor, 16680, Indonesia \\ ${ }^{2}$ Departemen Pemanfaatan Sumberdaya Perikanan, FPIK, IPB University, Bogor, 16680, Indonesia \\ *E-mail: teguh_santausa@apps.ipb.ac.id
}

\begin{abstract}
The supporting factor in creating a fish production database system is Law number 45 of 2009 about fisheries, article 46, paragraphs 1 and 2. The problem in Sukabumi Regency is the Marine and Fisheries Service does not have a fish production database system based on a website that includes Fish Landing Base. This study aims to develop a fish production database system in the fishing port class D (PPI). The method used in this research is the prototyping method. The superiority of fish production database systems based on the website can integrate the calculations from fish production per month so that there is no need to calculate or input data on fish production per year. Based on the results of the research, the fish production database system based on the website includes four fishing port (PPI) in Palabuhanratu Bay, including PPI Cisolok, PPI Ciwaru, PPI Ujung Genteng, and PPI Mina Jaya. Investors, fishermen, fish industry, researchers, and the general public can access fish production data and information on the website through the fish production menu per month, fish production menu per year, fish production menu for several years.
\end{abstract}

Keywords: database, fish production, system, website

\begin{abstract}
ABSTRAK
Faktor pendorong terciptanya sistem basis data produksi ikan adalah lahirnya kebijakan yang diterbitkan Pemerintah, yaitu UU No. 45 tahun 2009 tentang Perikanan pasal 46 ayat 1 dan 2. Permasalahan yang ada di Dinas Kelautan dan Perikanan Kabupaten Sukabumi adalah tidak adanya sistem basis data produksi ikan berbasis situs web (website) yang mencakup Pangkalan Pendaratan Ikan (PPI). Tujuan dari penelitian ini adalah menyusun sistem basis data produksi ikan berbasis situs web (website) di pelabuhan perikanan kelas D (PPI). Metode yang digunakan dalam penelitian ini adalah metode pembuatan prototipe (prototyping). Keunggulan dari sistem basis data produksi ikan berbasis situs web (website) adalah kemampuan mengintegrasikan perhitungan dari produksi ikan per bulan, sehingga tidak perlu melakukan perhitungan atau memasukan (input) data produksi ikan per tahun. Berdasarkan hasil penelitian, sistem basis data produksi ikan berbasis situs web (website) mencakup empat Pangkalan Pendaratan Ikan (PPI) di Teluk Palabuhanratu, diantaranya PPI Cisolok, PPI Ciwaru, PPI Ujung Genteng, dan PPI Mina Jaya. Investor, nelayan, pengolah ikan, peneliti, dan masyarakat dapat mengakses data dan informasi produksi ikan di situs web (website) melalui menu produksi ikan per bulan, menu produksi ikan per tahun, menu produksi ikan selama beberapa tahun.
\end{abstract}

Kata kunci: basis data, produksi ikan, sistem, situs web

\section{PENDAHULUAN}

Faktor pendorong terciptanya sistem basis data produksi ikan adalah lahirnya kebijakan yang diterbitkan Pemerintah, yaitu
UU No. 45 tahun 2009 tentang Perikanan pasal 46 ayat 1 dan 2. Pasal 46 ayat 1 menyebutkan bahwa Pemerintah dan Pemerintah Daerah menyusun dan mengembangkan sistem informasi dan data statistik 
perikanan. Pemerintah dan pemerintah daerah juga melakukan tahap pengumpulan, pengolahan, analisis penyimpanan, penyajian, dan penyebaran data potensi. Pasal 46 ayat 2 disebutkan juga Pemerintah dan Pemerintah Daerah mengadakan pusat data dan informasi perikanan untuk menyelenggarakan sistem informasi dan data statistik. Berdasarkan Undang-Undang Nomor 14 Tahun 2008 tentang keterbukaan informasi publik pasal 3 butir (b) tujuan dari tersedianya data dan informasi dari Pemerintah adalah mendorong partisipasi masyarakat dalam proses pengambilan kebijakan publik. Pasal 2 ayat 3 juga menjelaskan setiap data dan informasi yang disediakan untuk publik harus diperoleh dengan cepat dan tepat waktu, biaya ringan, dan sederhana.

Kewajiban menyusun dan mengembangkan sistem informasi dilakukan untuk mendukung pelaksanaan evaluasi dan pelaporan di bidang pengelolaan sumber daya ikan dan lingkungan. Keberadaan sebuah sistem informasi dalam pengelolaan sumberdaya ikan dan lingkungan sangat penting dilakukan untuk mempercepat pemrosesan data (data processing) menjadi informasi dan memperluas akses data. Selain itu, sistem informasi juga sebagai pusat pengawasan sumberdaya ikan dan aktivitas penangkapan ikan bagi pemerintah.

Perkembangan teknologi informasi dan komunikasi saat ini sangat berkembang pesat. Penggunaan teknologi informasi yang dulunya masih berbasis luar jaringan (offline) (tidak terhubung satu sama lain dalam suatu jaringan), saat ini sudah menjadi daring (online). Hal ini memudahkan pengguna mendapatkan data dan informasi tanpa membutuhkan waktu dan biaya yang banyak serta tidak ada batasan jarak. Salah satu teknologi informasi yang dapat mengakses data dan informasi secara cepat, membutuhkan biaya murah, dan tanpa ada batasan jarak adalah situs web (website) (Parasaorantua et al., 2017).

Pemerintah Pusat yang mengelola Pelabuhan Perikanan Samudra (PPS),
Pelabuhan Perikanan Nusantara (PPN), dan Pelabuhan Perikanan Pantai (PPP) sudah memiliki sistem basis data produksi ikan berbasis situs web (website) dengan nama Pusat Informasi Pelabuhan Perikanan (PIPP). PIPP menampilkan data dan informasi tentang pengelolaan hasil tangkapan yang didaratkan di pelabuhan perikanan serta berperan sebagai pusat informasi antar pelabuhan perikanan di Indonesia. Potensi yang dimiliki pelabuhan perikanan di Indonesia yang dapat diakses secara luas/daring (online) ini terdapat kendala. Situs web (website) tidak mencakup PPI yang dikelola Unit Pelaksana Teknis Daerah (UPTD) Pemerintah Daerah. Berdasarkan Permen KP No.8 tahun 2012 tentang Kepelabuhan Perikanan pasal 21 dijelaskan bahwa, pelabuhan perikanan yang dikelola UPTD merupakan pelabuhan perikanan yang dibangun oleh Pemerintah Daerah.

Menurut Ditjen Perikanan Tangkap (2019), pelabuhan perikanan terbanyak di Wilayah Pengelolaan Perikanan Republik Indonesia (WPP RI) adalah pelabuhan perikanan kelas D dengan persentase $80,8 \%$ (274 PPI), kelas C sebanyak 11,8\% (40 PPP), kelas B sebanyak 5,3\% (18 PPN), dan kelas A sebanyak 2\% (7 PPS). Jumlah pelabuhan perikanan kelas D (PPI) yang besar ini ditambah dengan ketersediaan akses data produksi ikan yang masih di luar jaringan (offline). Hal ini membuat investor, nelayan, pengolah ikan, peneliti, masyarakat harus datang langsung ke Dinas Kelautan dan Perikanan Kabupaten Sukabumi untuk mencari data dan informasi produksi ikan.

Upaya untuk menjawab permasalahan diatas dibutuhkan sejumlah data yang diantaranya data produksi ikan setiap PPI di Teluk Palabuhanratu. Data yang dibutuhkan tersebut kemudian dilakukan suatu analisis, yaitu menggunakan analisis ikan ekonomis penting. Hasil analisis menampilkan suatu menu di dalam sistem basis data berbasis situs web (website), diantaranya menu produksi ikan per bulan, dan menu produksi ikan per tahun. Berdasarkan permasalahan 
yang sudah dijelaskan, studi ini bertujuan untuk menyusun sistem basis data produksi ikan berbasis situs web (website) di pelabuhan perikanan kelas D (PPI). Penelitian ini nantinya akan diterapkan di PPI yang ada di Teluk Palabuhanratu dan akses data produksi ikan dapat diakses melalui perangkat elektronik.

\section{METODE PENELITIAN}

\subsection{Waktu dan Tempat Penelitian}

Penelitian ini dilaksanakan di

Kabupaten Sukabumi, dengan lokasi survei di 4 PPI yaitu: PPI Ujung genteng, PPI Ciwaru, PPI Cisolok, dan PPI Mina jaya (Figure 1). Pemilihan lokasi ini dimaksudkan supaya peng-gambaran kondisi Teluk Palabuhanratu yang menjadi tempat pendaratan ikan lebih representatif. Penelitian ini dilaksanakan pada tanggal 1 Desember 2019 sampai dengan tanggal 29 Februari 2020.

\subsection{Metode Pengumpulan Data}

Data yang dibutuhkan dalam penelitian ini adalah data sekunder, diantaranya data produksi ikan selama 5 tahun terakhir (2015 sampai dengan 2019) per PPI dan data logbook harian selama 5 tahun terakhir (2015 sampai dengan 2019). Data Sekunder diperoleh dari Dinas Kelautan dan Perikanan Kabupaten Sukabumi, Jawa Barat.

\subsection{Analisis Data}

\subsubsection{Diagram Aliran Data (DAD)}

Diagram Aliran Data (DAD) adalah salah satu metode pemodelan yang digunakan dalam merancang dan menjelaskan suatu sistem informasi dalam bentuk diagram. Selain itu, kegunaan dari DAD menggambarkan aliran data dan pengolahan yang dilakukan sistem informasi. Kelebihan membuat DAD untuk sistem basis data produksi ikan berbasis situs web (website) adalah memudahkan peneliti untuk memvi-

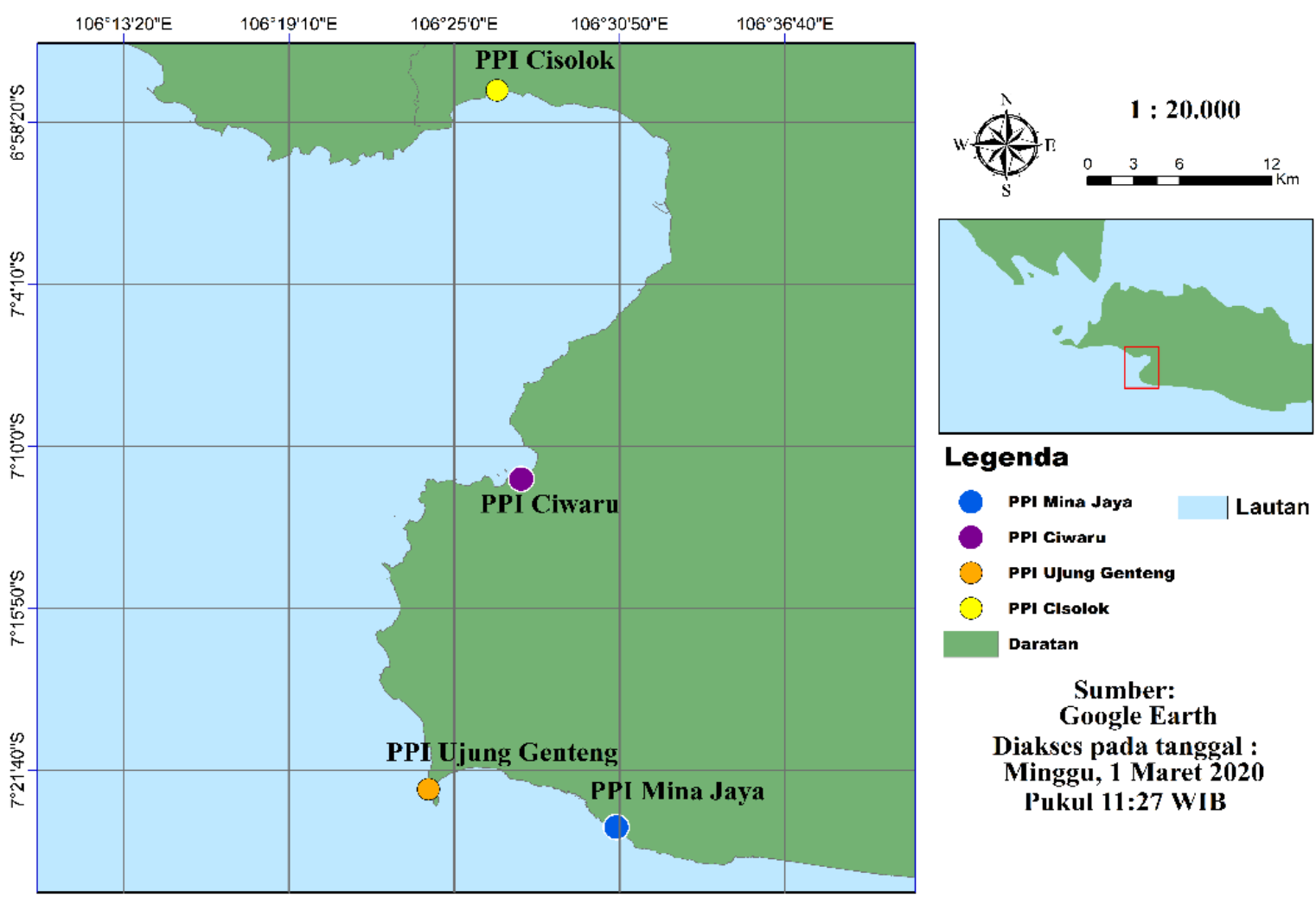

Figure 1. Map of research location. 


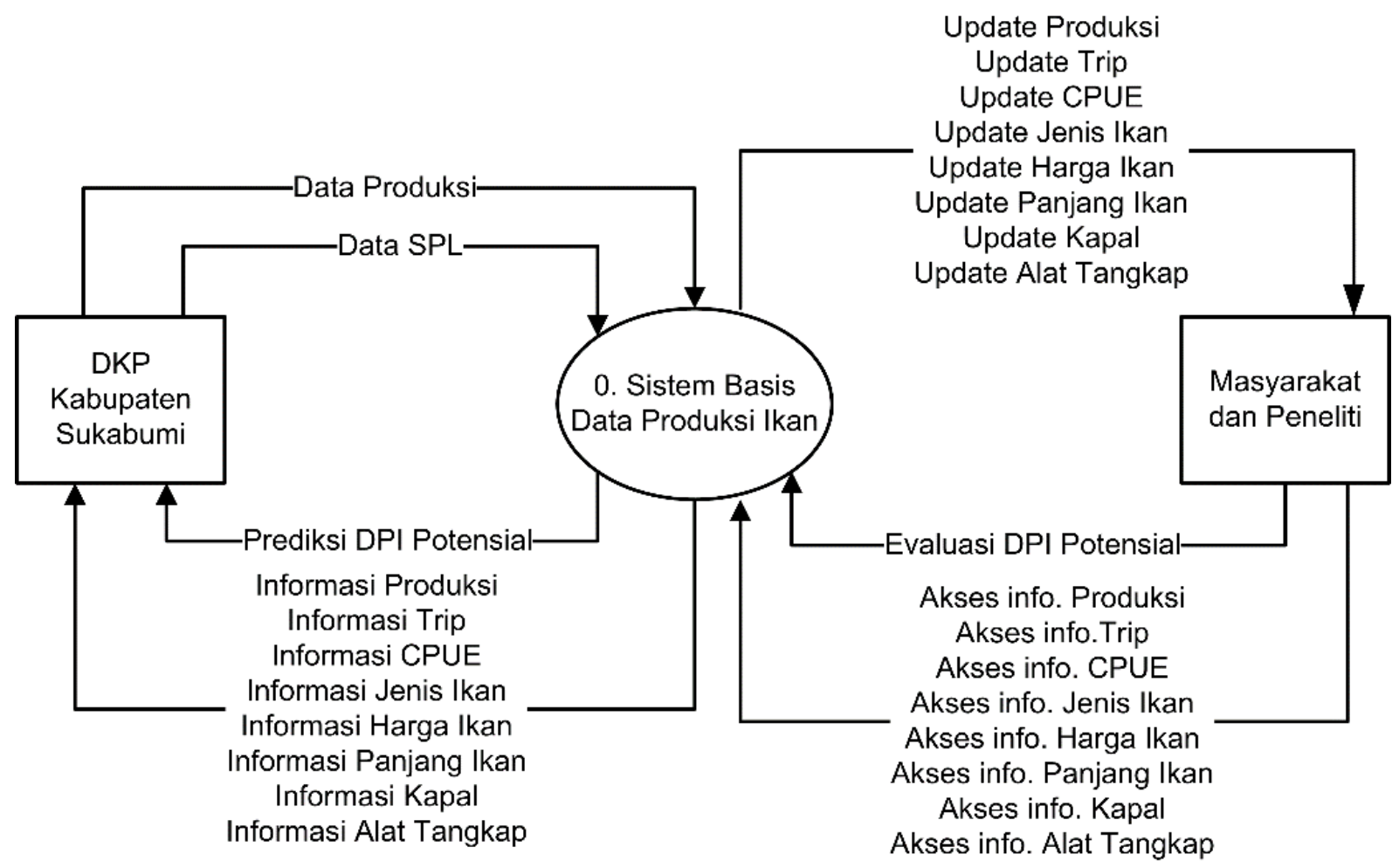

Figure 2. Fish production database system.

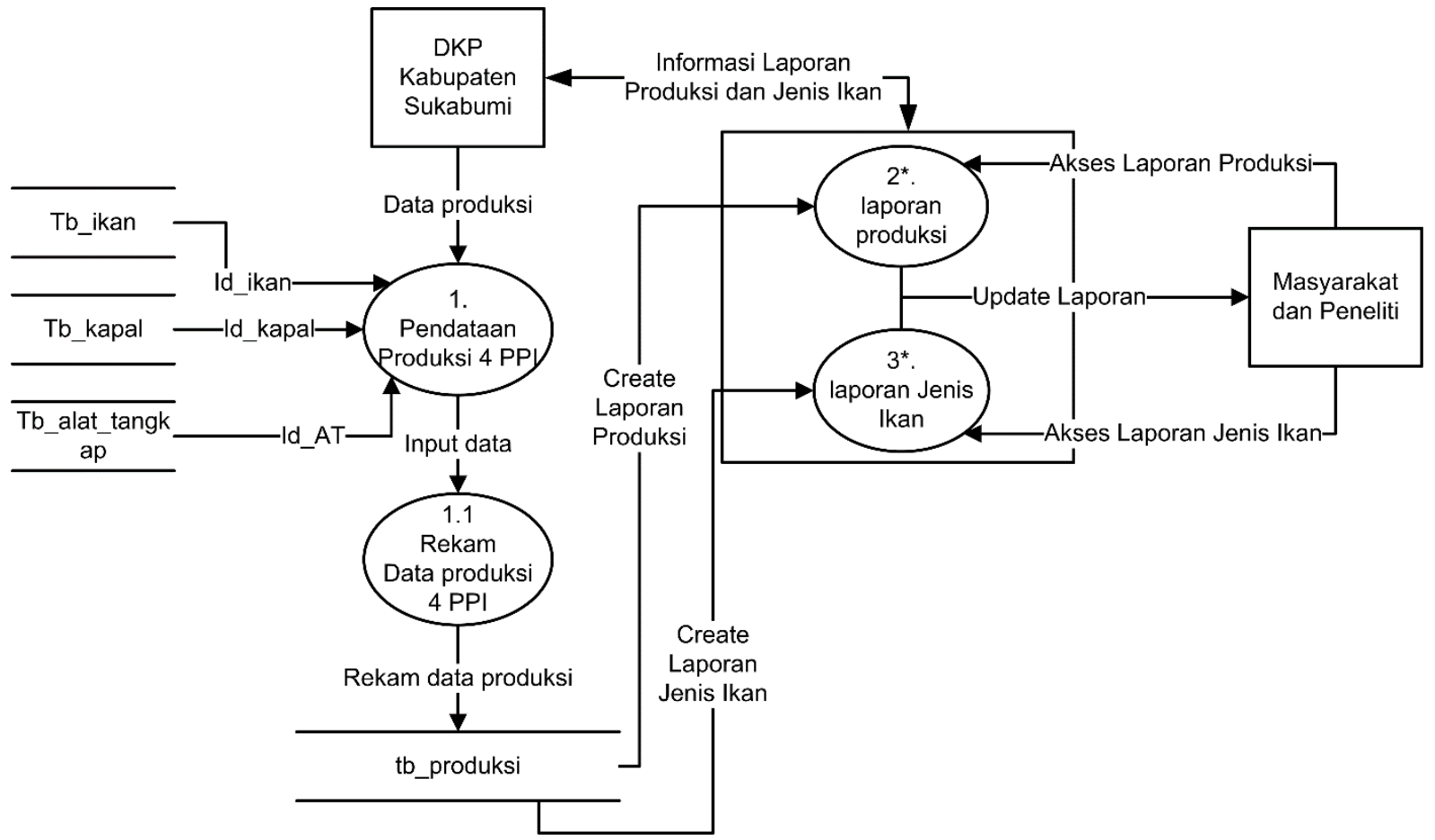

Figure 3. Fish production data collection system.

sualisasikan arus data yang diperlukan DAD level 0 (Figure 2) menjelaskan proses pengguna sistem informasi (Kosasih, 2006). alur perpindahan data dari adanya sistem 
informasi secara umum. Secara umum, DKP Kabupaten Sukabumi memasukkan data produksi ke sistem. Sistem basis data nantinya akan memberikan informasi produksi ikan, nilai produksi ikan, dan ikan ekonomis penting. Informasi disajikan mulai dari per bulan dan per tahun. Informasi yang ada di dalam sistem basis data produksi ikan ini dapat diakses secara luas oleh masyarakat melalui situs web (website).DAD level 1 proses 1 (Figure 3) yaitu sistem pendataan produksi, data produksi ke empat PPI akan direkam ke penyimpanan (storage) yang bernama "tb_produksi". "tb_produksi" merupakan tabel yang di dalam basis data (database) sistem informasi, berisikan data terkait produksi ikan di PPI Teluk Palabuhanratu. Di dalam penyimpanan (storage) "tb_produksi" terdapat juga id tabel "tb_ikan", "tb_kapal",

dan "tb_alat_tangkap". "tb_ikan" merupakan tabel yang memuat data tentang jenis ikan yang ada di Teluk Palabuhanratu. "tb_kapal" merupakan tabel yang memuat data tentang jenis-jenis kapal yang ada di Teluk Palabuhanratu. "tb_alat_tangkap" merupakan tabel yang memuat data tentang jenis-jenis alat tangkap yang digunakan di Teluk Palabuhanratu. Gabungan dari ketiga tabel tersebut dapat membuat informasi produksi ikan, nilai produksi ikan, dan jenis ikan ekonomis penting.

\subsubsection{Pembuatan Situs Web (Website)}

Pembuatan sistem basis data produksi ikan berbasis situs web (website) dibangun menggunakan metodologi pembuatan prototipe (prototyping). Pembuatan prototipe atau prototyping adalah proses mengubah kebutuhan menjadi suatu perintah di dalam sistem informasi berbasis situs web (website), perubahan ini dilakukan secara terus menerus sampai tidak adanya umpan balik (feedback) dari pengguna (user) untuk perbaikan. Perbaikan ini melibatkan kerja-sama pengguna (user) dan peneliti dalam membuat sistem informasi berbasis situs web (website) (Fatta, 2007).
Adapun langkah-langkah dari metodologi prototipe (prototyping) yang digunakan di dalam penelitian ini dapat dijabarkan sebagai berikut: Peneliti sebagai analis dan pembuat situs web (website), mengidentifikasi permasalahan dari kebutuhan pengguna (user) yaitu DKP Kabupaten Sukabumi. Peneliti membuat (build) sistem basis data produksi ikan berbasis situs web (website) berdasarkan kebutuhan pengguna (user). Sistem basis data produksi berbasis situs web (website) diberikan ke pengguna (user) untuk digunakan dan menyampaikan umpan balik (feedback) ke peneliti, apabila umpan balik (feedback) yang disampaikan ke peneliti terdapat perbaikan (revise), maka peneliti melakukan perbaikan (revise). Hasil perbaikan akan digunakan kembali oleh pengguna (user), apabila umpan balik (feedback) yang diberikan pengguna (user) tidak ada perbaikan, maka sistem basis data produksi ikan berbasis situs web (website) dapat digunakan.

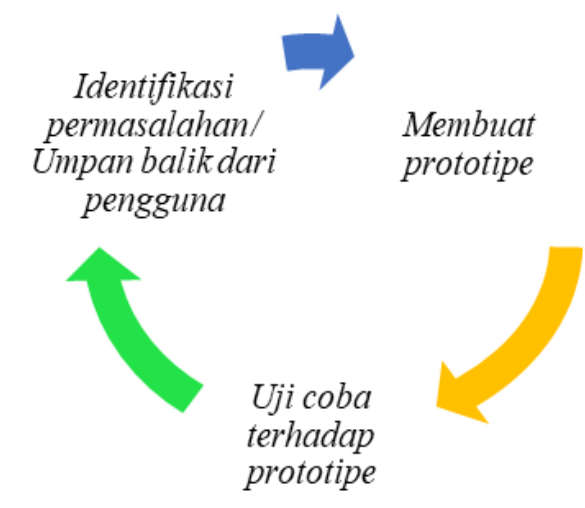

Figure 4. Prototyping method.

\section{HASIL DAN PEMBAHASAN}

\subsection{Rancangan Sistem Basis Data}

Pembuatan basis data (database) dan tabel pada situs web (website) ini menggunakan perangkat lunak (software) phpMyAdmin version 3.2.4. PhpMyadmin adalah perangkat lunak bebas (freeware) yang ditulis dalam bahasa pemrograman $p h p$ yang digunakan untuk mengelola basis data (database) MySQL melalui Jejaring Jagat 


\begin{tabular}{|c|c|c|c|c|c|c|c|c|c|c|c|c|}
\hline \multirow{2}{*}{\multicolumn{2}{|c|}{ PAs localhost/localhost/ppi / phpM $\times$}} & \multirow{2}{*}{\multicolumn{11}{|c|}{+}} \\
\hline & & & & & & & & & & & & \\
\hline$\leftarrow \rightarrow$ C $\quad$ (i) localhos & \multicolumn{12}{|c|}{ (i) localhost/phpmyadmin/index.php?db=ppi\&token=9ceac5cc9c8c5b8817bf481c4de5da } \\
\hline \multirow{3}{*}{ 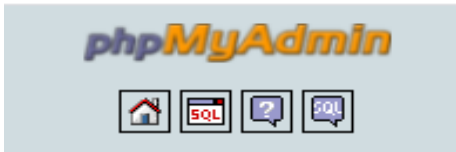 } & \multicolumn{12}{|c|}{ 氙量 Server: localhost } \\
\hline & \multicolumn{2}{|c|}{ 畨 Structure } & \multirow{2}{*}{ e } & \multicolumn{2}{|c|}{ Search } & \multicolumn{3}{|c|}{ 勇Query } & \multicolumn{2}{|c|}{ 镭Export } & \multicolumn{2}{|c|}{ 觬 Import } \\
\hline & & Tab & & & & Acti & ion & & & $\operatorname{Rec}$ & ords $^{1}$ & $\bar{T}$ \\
\hline Database & $\square$ & admin & & 謴目 & 雨 & 国祭 & 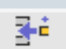 & 血 & $\times$ & & 6 & Innc \\
\hline ppi (15) & $\square$ & alat_tan & kap & 圆目 & 雨 & 应照 & 童㙂 & 而i & $\times$ & & 3 & Myl \\
\hline \multirow{14}{*}{ 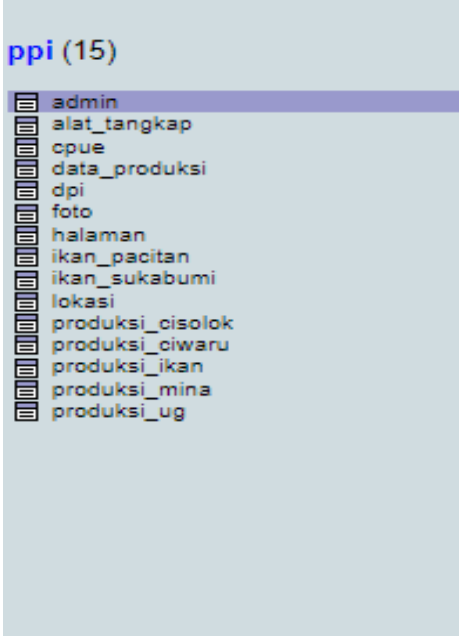 } & $\square$ & cpue & & 粗 & 画 & 国祭 & 굴 & 血 & $\times$ & & 11 & Myl \\
\hline & $\square$ & data_pr & duksi & 粗 & 画 & 国留 & 疍 & 而 & $\times$ & & 1,330 & Myl \\
\hline & $\square$ & dpi & & 击目 & 糟 & 国 & 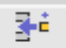 & 圌 & $x$ & & 4 & Myl \\
\hline & $\square$ & foto & & 畨 & 画 & 国祭 & 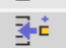 & 耍 & $x$ & & 2 & Myl \\
\hline & $\square$ & halama & & 圆国 & 줄 & 聂圆 & 감하 & 圌 & $x$ & & 23 & Myl \\
\hline & $\square$ & ikan_pa & :itan & 㘣目 & 凷 & 国祭 & 곤 & 耍 & $x$ & & 18 & Myl \\
\hline & $\square$ & ikan_su & rabumi & 粗 & 荬 & 国祭 & 감다 & 耍 & $x$ & & 62 & Myl \\
\hline & $\square$ & lokasi & & 贯 & 荬 & 国固 & zist & 耍 & $x$ & & 4 & Myl \\
\hline & $\square$ & produks & i_cisolok & 謴目 & 函 & 国国 & 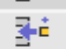 & 圌 & $x$ & & 1,188 & Myl \\
\hline & $\square$ & produks & i_ciwaru & 圆目 & 雨 & 聂 & 감. & 圌 & $x$ & & 929 & Myl \\
\hline & $\square$ & produks & i_ikan & 圊 & 雨 & 目祭 & 괍. & 耍 & $x$ & & 1,477 & Myl \\
\hline & $\square$ & produks & _mina & 㘣目 & 荬 & 国国 & z하. & 耍 & $x$ & & 1,777 & Myl \\
\hline & $\square$ & produks & i_ug & 贯 & 雨 & 国国 & 괍. & 耍 & $x$ & & 921 & Myl \\
\hline & & $15 \mathrm{t}$ & ble(s) & & & Su & & & & & 7,755 & Myl \\
\hline
\end{tabular}

Figure 5. Table structure in the database.

\begin{tabular}{|c|c|c|c|c|c|c|c|c|c|c|c|c|c|c|}
\hline & & & & & & & & & \multirow{2}{*}{ produksi_ciwaru } & \multirow[b]{2}{*}{ nilai_ciwaru } & \multirow[b]{2}{*}{ produksi_ug } & \multirow[b]{2}{*}{ nilai_ug } & \multirow[b]{2}{*}{ produksi_mina } & \multirow[b]{2}{*}{ nilai_mina } \\
\hline \multicolumn{3}{|c|}{ Options } & \multirow{2}{*}{$\begin{array}{r}\text { id } \\
1\end{array}$} & \multirow{2}{*}{$\begin{array}{c}\text { bulan } \\
\text { Januari }\end{array}$} & \multirow{2}{*}{$\begin{array}{l}\text { tahun } \\
2015\end{array}$} & ikan & produksi_cisolok & nilai_cisolok & & & & & & \\
\hline$\square$ & 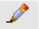 & $x$ & & & & 1 & 0 & 0 & 0 & 0 & 0 & 0 & 0 & 0 \\
\hline$\square$ & $\theta$ & $x$ & 2 & Januari & 2015 & Bawal & 0 & 0 & 0 & 0 & 211 & 3069000 & 100 & 1500000 \\
\hline$\square$ & 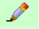 & $x$ & 3 & Januari & 2015 & Bronang & 0 & 0 & 0 & 0 & 0 & 0 & 25673 & 359422000 \\
\hline$\square$ & $\theta$ & $x$ & 4 & Januari & 2015 & 4 & 48168 & 687969000 & 10087 & 151305000 & 0 & 0 & 148102 & 2142759000 \\
\hline$\square$ & 8 & $x$ & 5 & Januari & 2015 & 5 & 0 & 0 & 0 & 0 & 0 & 0 & 0 & 0 \\
\hline$\square$ & 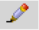 & $x$ & 6 & Februari & 2015 & 6 & 0 & 0 & 0 & 0 & 0 & 0 & 0 & 0 \\
\hline$\square$ & 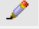 & $x$ & 7 & Februari & 2015 & 7 & 0 & 0 & 0 & 0 & 0 & 0 & 0 & 0 \\
\hline$\square$ & $\theta$ & $x$ & 8 & Februari & 2015 & 8 & 0 & 0 & 0 & 0 & 0 & 0 & 0 & 0 \\
\hline$\square$ & 8 & $x$ & 9 & Februari & 2015 & 9 & 0 & 0 & 0 & 0 & 0 & 0 & 0 & 0 \\
\hline$\square$ & $\theta$ & $x$ & 10 & Februari & 2015 & 10 & 0 & 0 & 0 & 0 & 0 & 0 & 0 & 0 \\
\hline$\square$ & 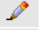 & $x$ & 11 & Maret & 2015 & 11 & 0 & 0 & 0 & 0 & 0 & 0 & 500 & 2500000 \\
\hline$\square$ & 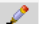 & $x$ & 12 & Maret & 2015 & 12 & 0 & 0 & 0 & 0 & 0 & 0 & 0 & 0 \\
\hline
\end{tabular}

Figure 6. Data in "fish_production" table.

Jembar (World Wide Web) (Barri et al., 2015).

Basis data pada situs web (website) diberi nama "ppi". Basis data (database) "ppi" mempunyai 15 struktur tabel (Figure 5). Setiap tabel merupakan tempat penyimpanan data (storage), seperti tabel bernama "produksi_ikan" yang merupakan pusat data produksi ikan selama beberapa tahun di empat lokasi Pangkalan Pendaratan Ikan-Kabupaten Sukabumi. Semua tabel di basis data (database) "ppi" dapat menerima arsip (file) dari ekstensi .csv dan .sql. Hal ini untuk menambah data produksi ikan dari tahun sebelumnya.

Berdasarkan Figure 6, tabel "produksi_ikan" mempunyai beberapa kolom (Table 1):

Table 1. Field column "produksi_ikan" table.

\begin{tabular}{ll}
\hline \multicolumn{1}{c}{ Coloum (field) } & \multicolumn{1}{c}{ Information } \\
\hline id & Jumlah record \\
bulan & Data bulan \\
tahun & Data tahun \\
\hline
\end{tabular}




\begin{tabular}{ll}
\hline \multicolumn{1}{c}{ Coloum (field) } & \multicolumn{1}{c}{ Information } \\
\hline ikan & Data jenis ikan \\
produksi_cisolok & Produksi (kg) di Cisolok \\
nilai_cisolok & $\begin{array}{l}\text { Nilai produksi (Rp) } \\
\text { di Cisolok }\end{array}$ \\
produksi_ciwaru & $\begin{array}{l}\text { Produksi (kg) } \\
\text { di Ciwaru }\end{array}$ \\
nilai_ciwaru & Nilai produksi (Rp) \\
& di Ciwaru \\
produksi_ug & Produksi (kg) di Ujung \\
& Genteng \\
nilai_ug & Nilai produksi (Rp) \\
& di Ujung Genteng \\
produksi_mina & Produksi (kg) di Mina \\
& Jaya \\
nilai_mina & Nilai produksi (Rp) \\
& di Mina Jaya \\
\hline
\end{tabular}

\subsection{Sistem Basis Data Produksi Ikan Berbasis Situs Web (Website)}

Sistem basis data produksi ikan berbasis situs web (website) diberikan ke pengguna (user) yaitu DKP Kabupaten Sukabumi dan Masyarakat umum untuk digunakan serta menyampaikan umpan balik (feedback) ke peneliti. Pengguna (user) nantinya menggunakan penjelajah web (web browser) seperti Google Chrome, Firefox, Internet Explorer, Opera, atau perangkat lunak berbasis penjelajah web (software web browser) lainnya untuk mengakses sistem basis data produksi ikan berbasis situs web (website) ini. Lokator Sumber Seragan (LSS) disebut juga URL (Uniform Resource Locator) diakses menggunakan jaringan lokal (Localhost) dari XAMPP, yaitu https://localhost/ppi/admin/login.php.

Nama pengguna (Username) yang ada didalam sistem basis data produksi ikan ini mempunya hak akses berbeda. Admin memiliki hak akses penuh dalam mengelola sistem basis data produksi ikan, sedangkan pengguna (user) selain admin hanya bisa mengakses menu-menu tertentu. Masyarakat umum hanya bisa mengakses informasi produksi ikan dan tidak dapat bisa merubah, atau menghapus data (Create, Update, dan Delete) yang di dalam sistem basis data produksi ikan. Username dan password dapat di input melalui halaman login website
(Figure 7).

Tampilan masukan (input) produksi ikan dapat dilihat pada Figure 8, tampilan ini merupakan hasil dari script php. Halaman ini hanya bisa diakses oleh administrator, untuk menjaga data agar tidak dapat dirubah/ dihapus (Create, Update, dan Delete) oleh pengguna (user) yang bukan haknya. Masukan (input) produksi ikan terdapat tombol simpan, agar formulir (form) yang sudah terisi dapat tersimpan di tabel "produksi_ikan".

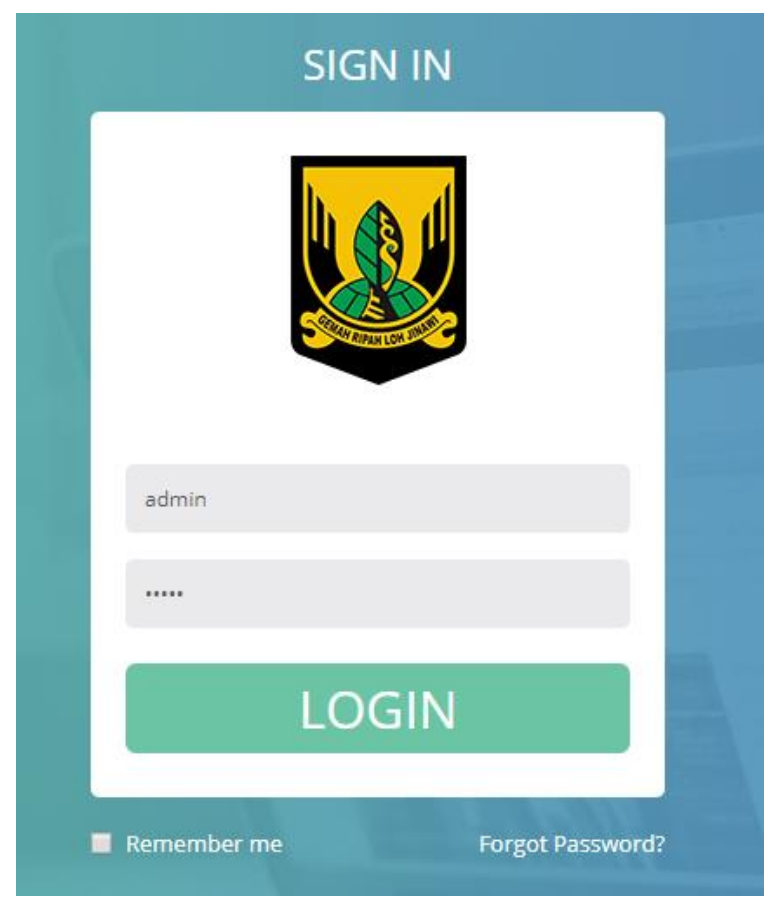

Figure 7. Display login website.

Berdasarkan laporan produksi ikan bulan Oktober-Desember 2019 terdapat 3 jenis ikan ekonomis penting yang memiliki kontinuitas. Ikan ekonomis tersebut adalah ikan layur, udang rebon, dan ikan tembang. Ikan layur memiliki produksi tertinggi pada bulan Desember sebesar $67.380 \mathrm{~kg}$ dengan nilai pasaran Rp34.558,00. Udang rebon memiliki produksi tertinggi pada bulan Oktober sebesar $61.600 \mathrm{~kg}$ dengan nilai pasaran Rp7.909,00. Ikan tembang memiliki produksi tertinggi pada bulan Desember sebesar $26.375 \mathrm{~kg}$ dengan nilai pasaran Rp15.000,00. 


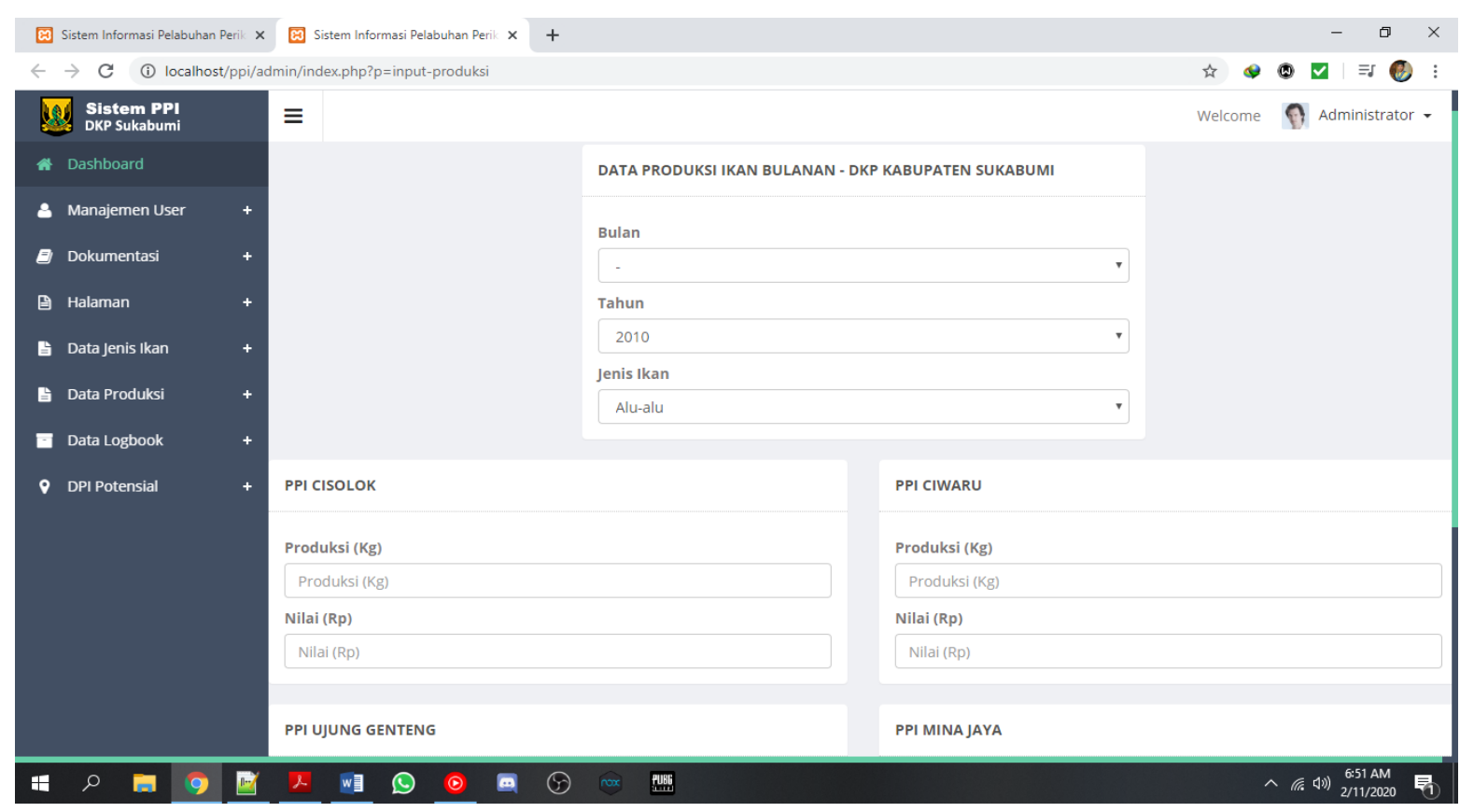

Figure 8. Display input fish production.

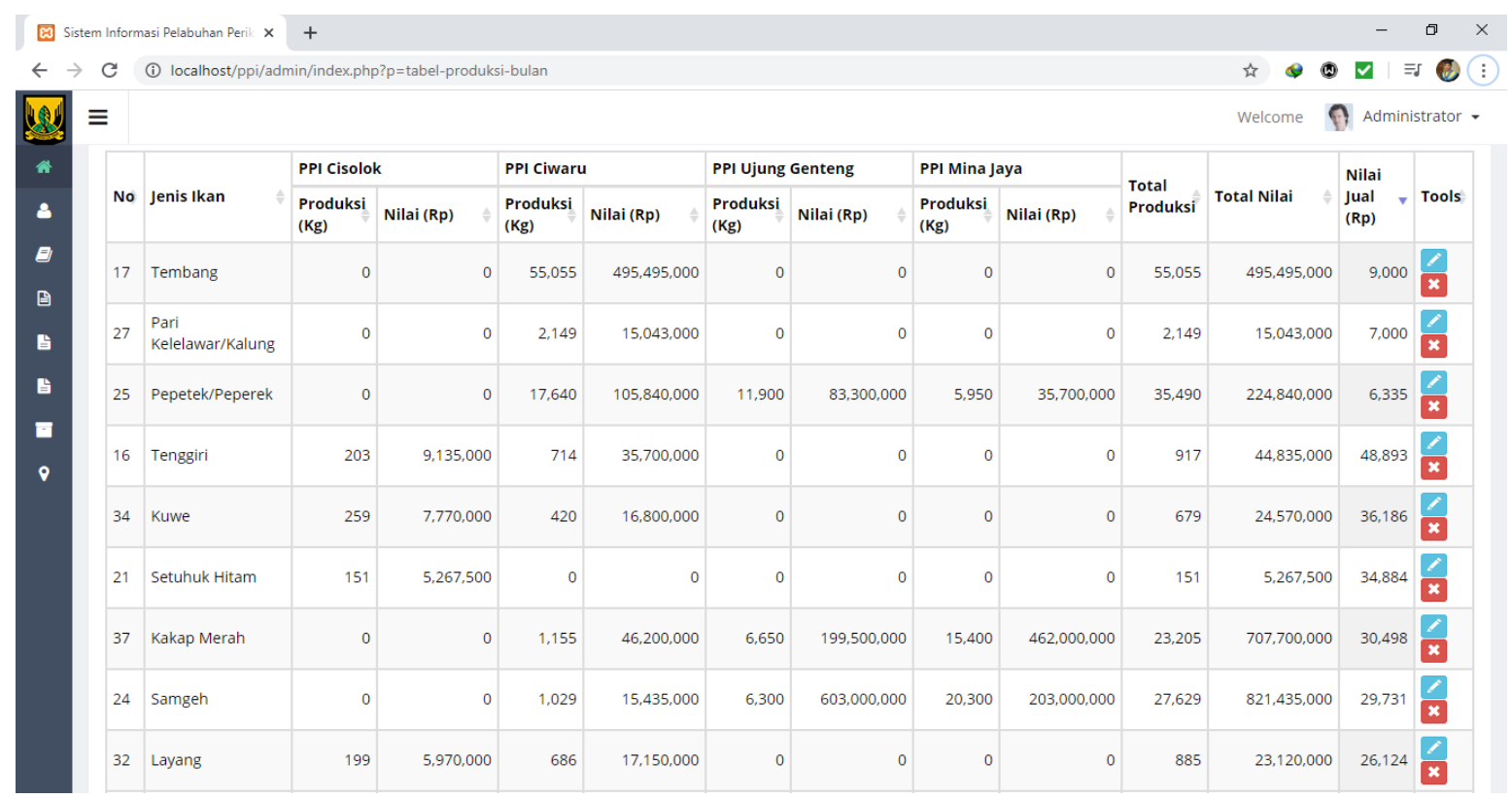

Figure 9. Display table of "fish_production" PPI per month.

Informasi mengenai produksi ikan ekonomis penting sangat bermanfaat bagi Industri Pengolah, terutama dalam menentukan jenis olahan. Pengolah akan memanfaatkan ikan yang memiliki volume tinggi, tapi rendah dari sisi harga (Hamzah et al., 2015). Melalui informasi ketersediaan ikan hasil tangkapan pada bulan tertentu, PPI di
Teluk Palabuhanratu dapat menjadi alternatif bagi pengolah ikan, apabila hasil tangkapan di PPN Palabuhanratu produksinya menurun. Hal ini bertujuan agar produksi bagi Pengolah ikan tetap berjalan.

Penelitian yang dilakukan Pane (2010) terkait dengan data dan informasi Kekuatan Hasil Tangkapan (KHT) menyim- 
pulkan bahwa: (1) ketersediaan jenis-jenis ikan bernilai ekonomis di suatu pelabuhan perikanan, akan mengakibatkan pedagang dan pengolah ikan tertarik melakukan pembelian di pelabuhan tersebut; (2) tidak tersedianya suatu jenis ikan yang dibutuhkan oleh pedagang atau pengolah ikan tersebut di pelabuhan perikanan, berdampak pada nelayan ataupun pengusaha penangkapan tertarik untuk melakukan pendaratan atau penjualan hasil tangkapannya di pelabuhan tersebut.

Informasi produksi ikan per tahun dapat dilihat pada Figure 10. Halaman ini terdapat fitur saring (filter) berdasarkan tahun yang akan dicari. Fitur Microsoft Excel juga terdapat pada halaman ini, dimana pengguna (user) dapat mengkonversikan tabel informasi produksi ikan per tahun ke dalam bentuk arsip (file) Microsoft Excel. Keunggulan utama dari produksi ikan per tahun ini adalah kemampuan mengintegrasikan perhitungan dari produksi ikan per bulan, sehingga tidak perlu melakukan perhitungan atau masukan (input) data produksi ikan per tahun. Tabel produksi ikan per tahun terdapat informasi tentang jumlah produksi ikan setiap PPI dan informasi jenis ikan ekonomis penting di Teluk Palabuhanratu-Kabupaten Sukabumi selama satu tahun.

Informasi produksi ikan tertinggi pada tahun 2019 adalah PPI Ciwaru sebesar $2.943 .320 \mathrm{~kg}$ dan nilai produksi Rp40.543.301.082,00. Produksi ikan terendah tahun 2019 adalah PPI Mina Jaya sejumlah $186.675 \mathrm{~kg}$ dan nilai produksi sebesar Rp5.214.941.000,00. Total keseluruhan produksi ikan dari 4 PPI di Teluk Palabuhanratu selama 2019 adalah 4.379.924 $\mathrm{kg}$ dan nilai produksi sebesar Rp77.486.056.229,00. Informasi jenis ikan ekonomis penting dapat dilihat dengan cara menyortir kolom Nilai Jual (tinggi-rendah). Menurut Genisa (1999), penentuan ikan ekonomis penting dilihat dari 2 hal, yaitu: (1) Memiliki nilai jual pasaran yang tinggi dan volume produksi yang tinggi juga; (2) Memiliki nilai pasaran murah/rendah dan volume produksi yang tinggi.

Berdasarkan informasi produksi ikan per tahun yang disajikan pada situs web (website), ikan ekonomis penting memiliki nilai pasaran murah/rendah dan volume

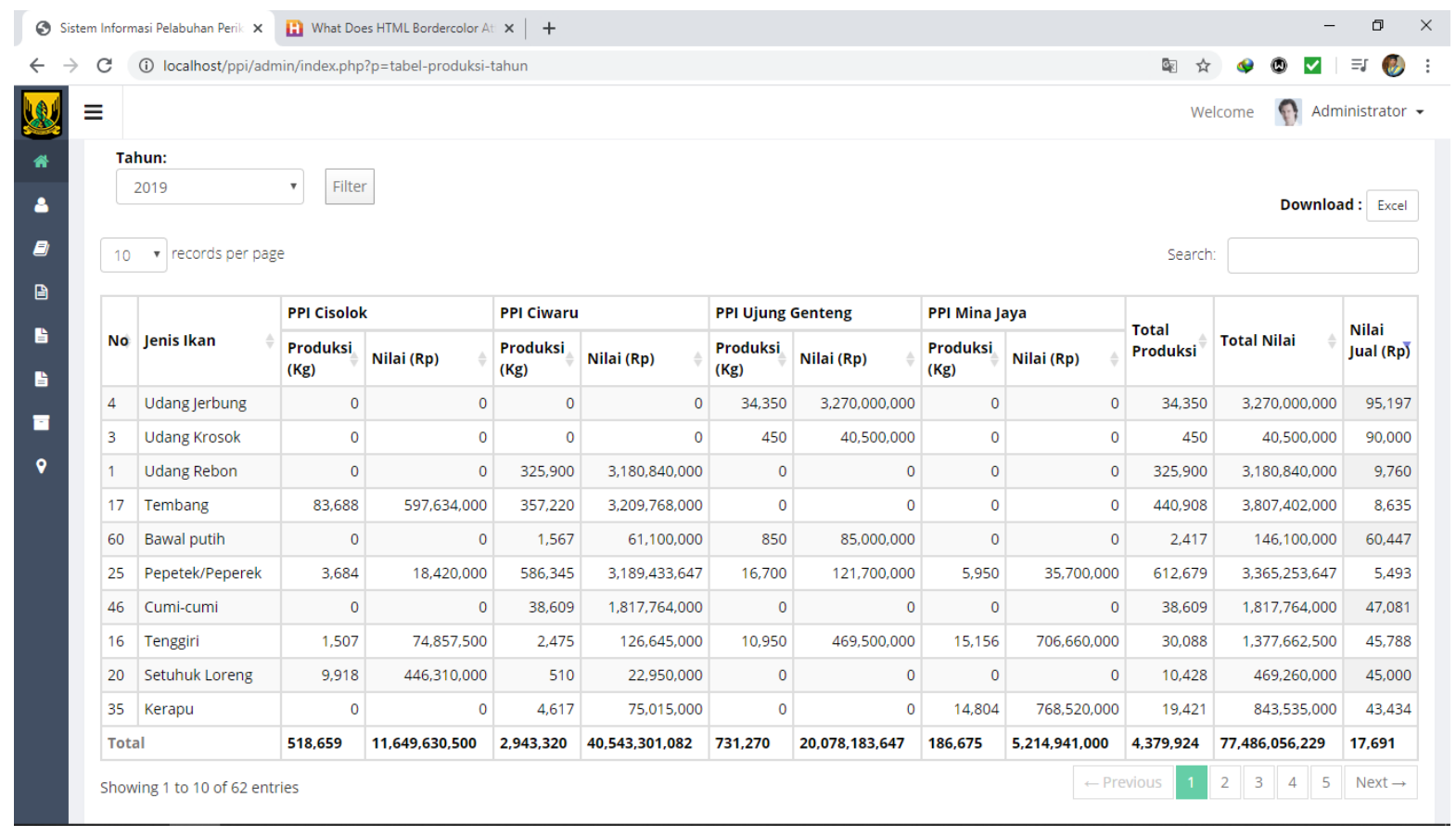

Figure 10. Display table "produksi_ikan" per year. 
produksi yang tinggi. Hal ini disebabkan karakteristik armada penangkapan ikan empat PPI di Teluk Palabuhanratu adalah motor tempel <5 GT (Nelayan skala kecil). Berdasarkan data statisik Dinas Kelautan dan Perikanan Kabupaten Sukabumi (DKP, 2019), jumlah motor tempel <5 GT sebesar 2.047 unit. Tentu ini yang menyebabkan kemampuan volume produksi menjadi terbatas, karna ukuran kapal yang kecil (<5 GT).

Ikan ekonomis penting di Teluk Palabuhanratu yang memiliki nilai pasaran rendah/murah dan volume produksi yang tinggi diantaranya udang rebon, ikan tembang, ikan pepetek/peperek, dan ikan layur. Udang rebon mempunyai nilai pasaran Rp9.760,00 dengan volume produksi $326.900 \mathrm{~kg}$. Ikan tembang mempunyai nilai pasaran Rp8.635,00 dengan volume produksi sebesar $440.908 \mathrm{~kg}$. Ikan pepetek/peperek mempunyai nilai pasaran Rp5.493,00 dengan volume produksi sebesar $612.679 \mathrm{~kg}$. Ikan layur mempunyai nilai pasaran Rp28.449,00 dengan volume produksi sebesar $730.955 \mathrm{~kg}$.

Berdasarkan produksi ikan selama 5 tahun terakhir (2015-2019), produksi ikan cenderung meningkat di Kabupaten Sukabumi (Figure 11). Tahun 2019 menjadi produksi tertinggi dengan nilai 4.379 ton, sedangkan produksi terendah pada tahun 2018 sebesar 1.925 ton. Rincian produksi ikan yang meningkat adalah 2015 (1.637 ton), 2016 (1.855 ton), 2017 (3.365 ton), 2018 (1.925 ton), dan 2019 (4.379 ton). Beberapa faktor yang menyebabkan produksi ikan meningkat. Menurut Mustaruddin (2015) menyatakan terdapat 2 faktor, yaitu: (1) Lokasi penangkapan ikan berada di jalur migrasi ikan dan (2) Perkembangan jumlah nelayan yang terlihat pada usaha perikanan tangkap terus bertambah seiring meningkatnya produksi ikan.

Tren produksi ikan yang cenderung meningkat menciptakan peluang investasi bagi industri perikanan, sehingga tujuan pembangunan nasional terkait ketersediaan sumberdaya protein dari ikan lebih terjamin dan pemanfaatan sumberdaya ikan juga lebih optimal (Mustaruddin \& Astarini, 2019). Keterkaitan produksi ikan yang meningkat sangatlah penting bagi pembangunan nasional jangka panjang. Berdasarkan arahan Rencana Pembangunan Jangka Panjang Nasional (RPJPN) 2005-2025 terkait pembangunan kelautan dan perikanan terdapat Misi-6 yaitu mewujudkan Indonesia yang asri dan lestari. Salah satu strategi yang dilakukan adalah terpeliharanya kekayaan keanekaragaman jenis sumber daya alam untuk mewujudkan daya saing bangsa dan modal pembangunan nasional.

Berdasarkan hasil yang dimuat dalam penelitian ini, sistem basis data produksi ikan berbasis situs web (website) memiliki

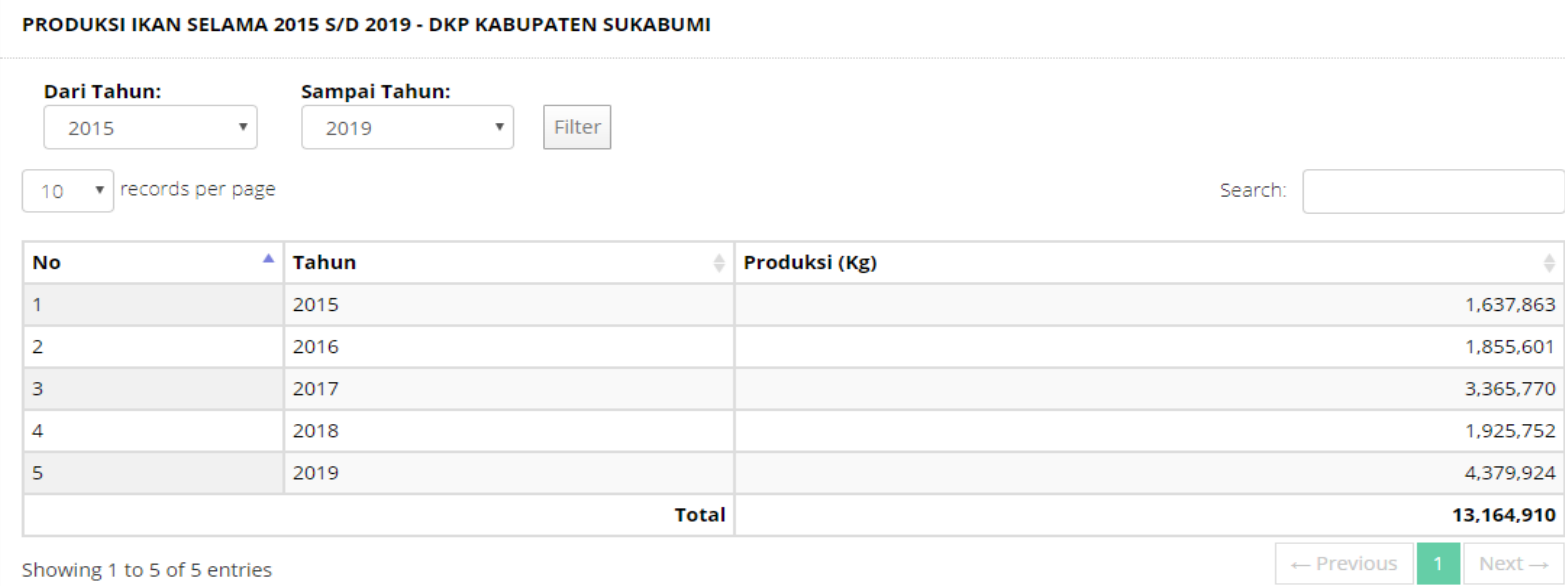

Figure 11. Fish production (2015-2019). 
kemampuan diantaranya sebagai berikut: informasi produksi ikan PPI yang ada di Teluk Palabuhanratu dapat diakses secara luas melalui perangkat elektronik (komputer, ponsel cerdas (smartphone), atau laptop) secara daring (online). Memberikan informasi ikan ekonomis penting di masingmasing PPI yang ada di Teluk Palabuhanratu per bulan. Mengintegrasikan perhitungan dari produksi ikan per bulan menjadi per tahun dari masing-masing PPI, sehingga tidak perlu melakukan perhitungan atau input data produksi ikan per tahun. Memberikan informasi terkait tren produksi ikan di Teluk Palabuhanratu untuk menciptakan peluang investasi.

Kemampuan yang dimiliki sistem basis data produksi ikan berbasis situs web (website) merupakan suatu keunggulan dibandingkan PIPP. Kemampuan yang dimiliki sistem basis data produksi ikan pada penelitian ini, tidak terdapat di PIPP. Menurut Mansur \& Kasmawi (2017), sistem basis data berbasis situs web (website) mempunyai keunggulan yaitu pengelolaan data dilakukan secara terpusat, pengguna (user) lebih mudah untuk mendapatkan data dan informasi karna tampilan situs web (website) yang mudah digunakan, dan sistem basis data dapat diakses pada saat yang sama dari lokasi yang berbeda. Sistem basis data perikanan berbasis situs web (website) memberikan informasi kepada masyarakat tentang potensi sumberdaya ikan di suatu daerah serta dapat dijadikan alat bantu pengolahan data perikanan bagi Dinas Kelautan dan Perikanan di daerah karena dapat menyimpan dan diakses dengan cepat/mudah (Reniban, 2019). Keunggulan sistem basis data produksi ikan menurut Haluan et al. (2012) adalah (1) mempermudah dalam penyimpanan dan pengolahan data produksi, (2) kecepatan menganalisis data produksi ikan, (3) memprediksi tingkat produksi ikan ekonomis penting dengan cepat, (4) pengoperasian lebih mudah dan cepat dibandingkan secara manual.
Sistem basis data produksi ikan berbasis situs web (website) tidak menutup kemungkinan terdapat kelemahan. Menurut Yudha \& Muryadi (2018), salah satu serangan yang dapat dilakukan dari sistem basis data berbasis situs web (website) adalah SQL Injection. Serangan ini dilakukan dengan cara memasukan perintah di LSS disebut juga URL. Teknik ini memungkinkan peretas (hacker) mengakses basis data secara tidak sah. Kelemahan ini tidak hanya berlaku pada penelitian ini tetapi penelitian yang terkait dengan sistem basis data dan informasi berbasis situs web (website), sehingga perlu adanya penelitian lanjutan yang membahas tingkat keamanan pada situs web (website).

\section{KESIMPULAN}

Sistem basis data produksi ikan berbasis situs web (website) mencakup empat Pangkalan Pendaratan Ikan (PPI) di Teluk Palabuhanratu, diantaranya PPI Cisolok, PPI Ciwaru, PPI Ujung Genteng, dan PPI Mina Jaya. Situs web (website) sistem basis data produksi ikan dapat diakses melalui penjelajah web (web browser) seperti Google Chrome, Firefox, Internet Explorer, Opera, dan lainnya. Investor, nelayan, pengolah ikan, peneliti, dan masyarakat dapat mengakses data dan informasi produksi ikan di situs web (website) melalui menu produksi ikan per bulan, menu produksi ikan per tahun, menu produksi ikan selama beberapa tahun. Ketiga menu tersebut, hanya dapat dimasukkan (input), dirubah (edit), atau dihapus (delete) oleh petugas PPI melalui halaman input_produksi.php.

\section{UCAPAN TERIMA KASIH}

Ucapan terima kasih disampaikan kepada Yayasan Alumni Peduli, Institut Pertanian Bogor (YAPI) dan Program Studi Teknologi Perikanan Laut-IPB yang telah mendukung penelitian ini. Penulis juga 
mengucapkan terima kasih yang tidak terhingga kepada dosen pembimbing yaitu Dr. Mustaruddin, STP dan Prof. Dr. Ir. Domu Simbolon, M.Si. yang telah mendukung penulis tanpa mengenal lelah.

\section{DAFTAR PUSTAKA}

Barri, M.W.H., A.S.M. Lumenta, \& A. Wowor. 2015. Perancangan aplikasi SMS Gateway untuk pembuatan kartu perpustakaan di Fakultas Teknik Unsrat. E-Journal Teknik Elektro dan Komputer, 1(1): 23-28.

https://doi.org/10.35793/jtek.4.1.2015 .6522

Ditjen Perikanan Tangkap. 2019. Pusat Informasi Pelabuhan Perikanan. Kementerian Kelautan dan Perikanan. Jakarta. 20 p.

Dinas Kelautan Perikanan (DKP). Kabupaten Sukabumi. 2019. Laporan Statistika Perikanan Tahun 2019. Pemerintah Daerah Kabupaten Sukabumi. Sukabmi, 109 p.

Fatta, H.A. 2007. Analisis dan perancangan sistem informasi. Andi Press. Yogyakarta. $211 \mathrm{p}$.

Genisa, A.S. 1999. Pengenalan jenis-jenis ikan laut ekonomi penting di Indonesia. Oseana, 24(1): 17-38.

http://oseanografi.lipi.go.id/perpustak aan/repository/showpdf/226

Hamzah, A., A.B. Pane, \& E. Lubis. 2015. Potensi unggulan sebagai bahan baku industri pengolahan di PPN Karangantu. Marine Fisheries, 6(1): 45-58. https://doi.org/10.29244/jmf.6.1.4558

Haluan, J., E.S. Wiyono, \& R. Supriyadi. 2012. Pengembangan sistem informasi manajemen perikanan tangkap dalam rangka pengembangan industrialisasi perikanan laut. Marine Fisheries, 3(2): 123-128. https://doi.org/10.29244/jmf.3.2.123128
Kosasih, S. 2006. Pemodelan sistem informasi dengan metode diagram arus data. J. IPREKAS, 5(1): 28-40. http://stmikpontianak.online/jurnal/?p ages $=$ read $\&$ id $=33$

Mansur \& Kasmawi. 2017. Pengembangan sistem database terpadu berbasis web untuk penyediaan layanan informasi website desa. TEKNOSI, 3(1): 73-82. https://doi.org/10.25077/TEKNOSI.v 3i1.2017.73-82

Mustaruddin, M.S. Baskoro, \& B. Purwanto. 2015. Pengembangan investasi usaha perikanan tangkap unggulan di BauBau, Sulawesi Tenggara. Prosiding Seminar Nasional Perikanan Tangkap IPB ke-6, Bogor, 22 Oktober 2015. 193-207 pp.

Mustaruddin \& J.E. Astarini. 2019. Model pengembangan usaha perikanan tangkap prospektif di Wilayah Perairan Aceh. Albacore, 3(2): 125134.

https://doi.org/10.29244/core.3.2.125 $-134$

Pane, A.B. 2010. Kajian kekuatan hasil tangkapan: Kasus Pelabuhan Perikanan Nusantara (PPN) Palabuhanratu Sukabumi. J. Mangrove dan Pesisir, 10(1): 8-19.

Parasaorantua, P.H., Y. Pasoreh, \& S.A. Rondonuwu. 2017. Implementasi teknologi informasi dan komunikasi (Studi Tentang Web e-Government di KOMINFO Kota Manado. E-J. Acta Diurna, 6(3): 1-14.

https://ejournal.unsrat.ac.id/index.php /actadiurnakomunikasi/article/view/1 7378

Reniban, L.E. 2019. Sistem informasi inventarisasi sumberdaya perikanan Kabupaten Maluku Tenggara dengan Metode Rapid Application Development. J. Teknik Komputer AMIK BSI, 5(2): 241-249. https://doi.org/10.31294/jtk.v5i2.546 3 
Yudha, F. \& A.M.P. Muryadi. 2018. Received : 16 March 2020 Perancangan aplikasi pengujian celah Reviewed : 19 April 2020 keamanan pada aplikasi berbasis web. Accepted : 14 August 2020 CyberSecurity dan Forensik Digital, 1(1): 1-6.

http://doi.org/10.14421/csecurity.201

8.1101 
